\title{
PERAN PARTAI POLITIK DALAM MENGGERAKKAN PARTISIPASI POLITIK RAKYAT
}

\begin{abstract}
Political participation is a citizen activity that acts as individuals intended to influence government decision making. Participation can be individual or collective, organized or spontaneous, peaceful or violent, legal or illegal, effective or ineffective. In general, Political Parties have a role as a means of political communication, the party plays a very important role in an effort to articulate interests or "political interests" that are hidden or sometimes hidden in society and combine with other political interests (political agrigation). Second, the Party as a means of political socialization. Political parties also play a role as a means of political socialization (instrument of political socialization). Third, political parties are a means of political recruitment. fourth, is the regulator and manager of conflicts that occur in the community (conflict management). There are several variables that can be used to explain why political participation is important, some of which are; (1) Political trust; (2) socio-economic status; (3) Personality or psychological explanation.
\end{abstract}

Keywords; Roles, Political Parties, Political Participation

\section{*Hasanudin}

\section{*Dosen Jurusan Ilmu Pemerintahan FISIP Universitas Riau}

\section{PENDAHULUAN}

Dalam bingkai demokrasi, partai politik merupakan salah satu variable yang berpengaruh terhadap peningkatan kualitas partisipasi politik rakyat dan pada gilirannya, peningkatan kualitas partisipasi politik rakyat mempengaruhi kapabilitas partai politik. Proposisi ini mengikuti alur berpikir yang dibangun Robert Dahl dengan memperkenalkan istilah "Poliarki” ("polyarchy") untuk menyebut demokrasi. Menurutnya ciri khas demokrasi adalah sikap tanggap pemerintah secara terus menerus terhadap preferensi atau keinginan warga negaranya. Tatanan politik demokrasi bisa digambarkan dengan memakai dua dimensi teoritik, yaitu seberapa tinggi tingkat kontestasi, kompetisi atau oposisi yang dimungkinkan dan seberapa banyak warga-negara yang memperoleh kesempatan berpartisipasi dalam kompetisi politik itu. ${ }^{1}$ Dua arena yang tergambar dalam dimensi teoritik yang digambarkan Dahl yaitu arena pemilihan umum dan arena pengambilan keputusan diluar pemilihan umum. Pada arena pemilihan umum dan di luar pemilihan umum partai politik adalah kontestan yang berkontestasi, berkompetisi dan atau beroposisi mengharapkan dukungan rakyat untuk mendapatkan posisi sebagai pihak yang dapat menjamin preferensi rakyat terlayani. Di pihak lain, rakyat pada dasarnya harus memiliki kesempatan ikut serta dalam kompetisi politik itu, memberi dukungan pada partai politik supaya aspirasi kepentingan mereka dikonversi sebagai kebijakan publik. 
Sejak bergulirnya reformasi politik lebih sepuluh tahun yang lalu, kontestasi, kompetisi atau oposisi diantara partai-partai politik secara legal formal sudah sedemikian terjamin walaupun dengan berbagai catatan pada implementasinya. ${ }^{2}$ Melalui undang-undang pemilihan umum dan undangundang partai politik serta undang-undang penyelenggara pemilu yang selalu direvisi, jaminan derajad kontestasi, kompetisi atau oposisi diatur sedemikian rupa. Permasalahan terletak pada derajad pelembagaan partai politik masing-masing, sehingga ada partai yang memiliki kapabilitas yang memadai menghadapi kontestasi, kompetisi atau oposisi dan ada partai politik yang kurang siap.

Hampir sama dengan kondisi partai politik, kesempatan rakyat berpartisipasi politik dalam arena pemilihan umum maupun forum pengambilan keputusan public yang lain di luar pemilihan umum masih sangat bervariasi. Meskipun secara legal formal terbuka kesempatan bagi setiap warga negara untuk mengambil bagian, tetapi tidak semua warga negara mampu keluar dari berbagai hambatan dan memandang kesempatan itu sebagai arena mengekspresikan hak-hak politik untuk mendorong perubahan. Realitas yang menjadi permasalahan adalah terdapat kecenderungan semakin rendah partisipasi pemilih justeru sejak reformasi digulirkan yang artinya pemilu semakin demokratis, sebagaimana tergambar pada table berikut:

\section{Tabel: Tingkat Partisipasi Politik Pemilih dan Dalam Pemilu di Indonesia}

\begin{tabular}{|c|c|c|}
\hline No. & Pemilu & $\begin{array}{c}\text { Tingkat Partisipasi } \\
\text { Politik (\%) }\end{array}$ \\
\hline 1. & 1955 & 91,4 \\
2. & 1971 & 96,6 \\
3. & 1977 & 96,5 \\
4. & 1982 & 96,5 \\
5. & 1987 & 96,4 \\
6. & 1992 & 95,1 \\
7. & 1997 & 93,6 \\
8. & 1999 & 92,6 \\
9. & Pileg 2004 & 84,1 \\
10 & Pileg 2009 & 71 \\
11 & Pileg 2014 & $67(75)$ \\
\hline
\end{tabular}

Sumber: Diolah dari KPU, BPS dan Kompas Pada pemilu legislatif 2014
Ketua KPU menyatakan partisipasi pemilih sebesar $75 \%$, tetapi jika dibandingkan jumlah DPT sebesar 185.826.024 orang dan jumlah suara sah sejumlah124.972.491 suara ${ }^{3}$, maka partisipasi pemilih hanya $67 \%$. Dari kecenderungan tersebut sangat wajar kalau ada upaya melihat peran apa saja yang dapat dilakukan khususnya oleh partai politik dalam menggerakan partisipasi politik rakyat?

\section{RUMUSAN MASALAH}

Berdasarkan latar belakang yang telah dijelaskan di atas, dapat dirumuskan pertanyaan penelitian adalah peran apa saja yang dapat dilakukan khususnya oleh partai politik dalam menggerakan partisipasi politik rakyat?

\section{KERANGKA TEOERI}

\section{a. Partisipasi Politik}

Sebelum membahas peran apa yang dapat dimainkan oleh partai politik untuk menggerak partisipasi politik rakyat, terlebih dahulu akan didudukan apa yang dimaksud partisipasi politik dan mengapa warga negara tidak berpartisipasi dalam kehidupan politik ? Secara konseptual partisipasi politik adalah kegiatan warga negara yang bertindak sebagai pribadi-pribadi yang dimaksudkan untuk mempengaruhi pengambilan keputusan pemerintah. Partisipasi bisa bersifat individual atau kolektif, terorganisir atau spontan, secara damai atau kekerasan, legal atau ilegal, efektif atau tidak efektif. ${ }^{4}$ Aktif berpartisipasi politik yaitu kegiatan individu warga negara mempengaruhi pengambilan keputusan politik yang tidak hanya terbatas pada ikut voting (dalam pemilihan umum) dan menjadi patriot (mendukung negara dengan mengibarkan bendera nasional atau ikut upacara kemerdekaan), tetapi lebih dari pada itu termasuk melakukan diskusi-diskusi politik dan terlibat dalam gerakan protes. 
Milbrath dan Goel mengajukan tiga bentuk partisipasi politik, yaitu partisipasi aktif, partisipasi pasif, dan apatis. ${ }^{5}$ Partisipasi aktif dibagi dalam dua kategori, yaitu partisipasi konvensional dan tidak konvensional. “Mode” partisipasi tidak konvensional ini adalah protestor, seperti bergabung dalam demontrasi massa di jalanan, gerakan-gerakan kekacauan (huru-hara), aksi protes menentang tindakan pemerintah yang secara moral dianggap salah, menolak untuk mentaati undang-undang atau kebijakan yang dianggap tidak adil, dan sebagainya. "Mode” partisipasi konvensional adalah aktifitass masyarakat (seperti bekerja bersama-sama menyelesaikan berbagai problem yang sedang dihadapi, membentuk suatu kelompok untuk bekerja dalam menyelesaiakan problem lokal, aktif menjadi anggota suatu organisasi masyarakat, berhubungan dengan pejabat pemerintah berkaitan dengan isu sosial tertentu, dan semacamnya); aktivis partai dan pekerja kampanye (bekerja secara aktif untuk partai atau kandidat, mempengaruhi orang lain untuk memilih, mengikuti pertemuan dan rapatrapat partai, menyumbang uang bagi partai atau kandidat, bergabung dan mendukung suatu partai politik, menjadi kandidat dalam suatu jabatan publik, dan sebagainya; komunikator (mencari informasi tentang politik, melibatkan diri dalam diskusi-diskusi politik, menyampaiakn dukungan atau protes pada elit politik, dan sebagainya; spesialis kontak (seperti menghubungi pejabat pemerintah baik di daerah maupun pusat jika ada masalah khusus yang berkaitan dengan kepentingannya, dan semacamnya. Sementara itu, “mode” partisipasi pasif adalah pemilih (voters) dan pecinta tanah air (patriots) seperti memilih secara teratur pada saat pemilihan, cinta negara, menunjukkan sikap patriotisme dengan mengibarkan bendera, mengikuti parade, membayar semua pajak dan retribusi, dan sebaganya. Sedangkan "mode" apatis adalah ketidakaktifan dalam proses politik, seperti tidak menghadiri pemilu, tidak ikut aktif di berbagai

Mengapa orang berpartisipasi dalam proses pembuatan dan pelaksanaan keputusan politik? Mengapa sebagian orang rela mengorbankan waktunya untuk memperjuangkan aspirasi dan kepentingan politiknya, sementara yang lain tidak? Mengapa sebagian orang rela diterpa hujan dan terik matahari untuk memprotes suatu kebijakan politik pemerintah, sementara yang lain tampak tak acuh? Mengapa sebagian orang bersedia antri mengikuti proses pemilihan umum sementara yang lain tidak? Variabel-variabel apa yang dapat menjelaskan keaktifan atau ketidakaktifan seseorang dalam kegiatan politik? Pertanyaan-pertanyaan senada masih dapat dikembangkan jika kita bermaksud untuk melakukan kajian tentang partisipasi masyarakat. Jawaban terhadap pertanyaan di atas, tentu saja, cukup variatif.

Salah satu variabel yang lazim digunakan untuk menjelaskan keaktifan atau ketidakaktifan seseorang dalam kegiatan politik adalah kepercayaan politik. Dalam literatur ilmu politik, konsep kepercayaan banyak digunakan untuk menjelaskan ketidakaktifan (inactivity) seseorang dalam dunia politik. Namun, menjelaskan ketidakaktifan dengan konsep kepercayaan selalu mengandung pengertian ganda: Pertama, ketidakaktifan dapat diinterpretasi sebagai ekspresi atas kepercayaan yang rendah terhadap sistem politik atau sebagai ekspresi atas perasaan keterasingan (alienasi); Kedua, ketidak aktifan juga dapat diinterpretasi sebagai ekspresi kepercayaan yang tinggi. Misalnya, ada bukti kuat bahwa partisipasi dalam sistem politik meningkat pada saat terjadi krisis. Dengan begitu, ketidakaktifan seseorang menandakan bahwa mereka puas terhadap sistem politik yang ada, atau paling tidak mereka tidak khawatir terhadap keadaan yang ada. Pengaruh kepercayaan politik harus dikaitkan dengan efikasi (informasi politik).Jika seseorang mempunyai tingkat efikasi (informasi politik) tinggi dan merasa pemerintah sebagian besar tidak dapat dipercaya (kepercayaan politik rendah), maka mereka akan menunjukkan derajat yang tinggi dalam aktivitas voting. Sementara itu, mereka yang tingkat efikasinya tinggi dan merasa sangat percaya terhadap pemerintah, maka akan menunjukkan derajat yang tinggi dalam aktivitas hak-hak sipil. Namun, jika variabel efikasi 
rendah, maka kedua hubungan ini tidak berlaku. ${ }^{6}$

Variabel lain yang yang lazim digunakan untuk menjelakan partisipasi masyarakat dalam proses politik adalah status sosial-ekonomi. Setidaknya ada tiga indikator yang biasa digunakan mengukur variabel status sosial-ekonomi, yaitu tingkat pendidikan, tingkat pendapatan dan pekerjaan. Tesis utama yang biasa dipakai adalah, tingkat partisipasi politik (dalam pemilu misalnya) berkorelasi secara signifikan dengan tingkat pendidikan dan pendapatan. Tesis ini sebenarnya bermula dari banyaknya temuan penelitian tentang perilaku memilih, yang menunjukkan tingginya tingkat kehadiran pemilih dari pemilih yang berpendidikan dan berpenghasilan tinggi. Hasil temuan Verba dan Nie menyimpulkan, "the bestknown about turnout is that citizens of higher social and economic status participate more in politics...."7 Ada beberapa alasan mengapa tingkat status sosial- ekonomi berkorelasi dengan keaktifan atau ketidakaktifan seseorang dalam kegiatan politik, khususnya pada saat pemilu. Pertama, tingkat pendidikan tinggi menciptakan kemampuan lebih besar untuk mempelajari kehidupan politik tanpa rasa takut, disamping memungkinkan seseorang menguasai aspek-aspek birokrasi dan aturan main yang ada. Kedua, pekerjaan-pekerjaan tertentu lebih menghargai partisipasi warga dibanding pekerjaan lainnya. Ketiga, pendapatan yang tinggi memudahkan orang untuk menanggung beban finansial akibat keterlibatannya dalam proses politik. ${ }^{8}$

Disamping variabel-variabel di atas, variabel lain yang juga lazim digunakan untuk menjelaskan keaktifan atau ketidakaktifan seseorang dalam proses politik adalah variabel kepribadian atau penjelasan psikologis. Penjelasan psikologis pada dasarnya dapat dikelompokkan dalam dua kategori, yaitu penjelasan-penjelasan yang lebih menitikberatkan faktor kepribadianindividual dan penjelasan- penjelasan yang lebih menitikberatkan orientasi kepribadian. Penjelasan faktor kepribadian-individual melihat bahwa ketidakaktifan seseorang dalam kegiatan politik, terutama dalam kegiatan pemilu, disebabkan oleh kepribadian yang tidak toleran, otoriter, tak acuh, perasaan tidak aman, perasaan khawatir, kurang mempunyai tanggung jawab secara pribadi, dan semacamnya. Orang yang mempunyai kepribadian yang tidak toleran atau tak acuh cenderung untuk tidak aktif dalam politik. Sebab, apa yang diperjuangkan elit politik tidak selalu sejalan dengan kepentingan perorangan secara langsung, betapapun mungkin hal itu menyangkut kepentingan umum yang lebih luas. Dalam konteks semacam ini, para seseorang yang mempunyai kepribadian tidak toleran atau tak acuh cenderung menarik diri dari percaturan politik langsung, karena menganggap kegiatan politik tidak berhubungan dengan kepentingannya.

Sementara itu, penjelasan psikologis yang lebih menitikberatkan faktor orientasi kepribadian melihat bahwa ketidakaktifan disebabkan oleh orientasi kepribadian pemilih yang menunjukkan karakteristik apatis, anomi, dan alienasi. ${ }^{9}$ Perasaan apatis sebenarnya merupakan jelmaan atau pengembangan lebih jauh dari kepribadian otoriter, yang secara sederhana ditandai dengan tiadanya minat terhadap persoalan- persoalan politik. Hal ini bisa disebabkan oleh rendahnya sosialisasi atau rangsangan(stimulus) politik, atau adanya perasaan (anggapan) bahwa aktvitas politik tidak menyebabkan perasaan kepuasan atau hasil secara langsung.

Anomi merujuk pada perasaan tidak berguna. Mereka melihat bahwa aktivitas politik sebagai sesuatu yang sia-sia, karena mereka merasa tidak mungkin mempengaruhi peristiwa atau kebijaksanaan politik. Bagi para orang semacam ini, keaktifan atau ketidakaktifan tidak mempunyai pengaruh apa-apa, karena keputusan-keputusan politik seringkali berada di luar kontrol masyarakat luas. Sebab, para terpilih biasanya menggunakan logika-logikanya sendiri dalam mengambil berbagai keputusan politik, dan dalam banyak hal mereka berada jauh di luar jangkauan masyarakat. Perasaan powerless inilah yang disebut sebagai anomi. Sedangkan alienasi berada di luar apatis dan anomi. Alienasi merupakan perasaan keterasingan secara aktif. Pemerintah dianggap 
tidak mempunyai pengaruh — terutama pengaruh baik — terhadap kehidupan seseorang. Bahkan pemerintah dianggap sebagai sesuatu yang mempunyai konsekuensi jahat terhadap kehidupan manusia. Jika perasaan alienasi ini memuncak, mungkin akan mengambil bentuk aksi politik politik nonkonvensional, seperti melalui kerusuhan, kekacauan, demonstrasi, dan semacamnya. Meskipun begitu, beberapa ahli menilai bahwa ketidaktertarikan terhadap politik dan rendahnya kepercayaan terhadap sistem serta perasaan powerless dalam mempengaruhi kebijaksanaan pemerintah bukanlah gejala psikologis, tetapi lebih disebabkan oleh struktur sosial dan kekuasaan yang tidak adil. Sherman dan Kolker mencatat, "Another explanation for nonvoting is lack of interest in politics and certain people's belief that they are powerless to influence political decisions. Such an orientation reflects not deapseated personality disorders but a healthy adaption to the reality of the unequal distribution of power in society". ${ }^{10}$ Beberapa faktor lingkungan (di luar variabel kepribadian atau penjelasan psikologis) yang mempunyai peran besar terhadap partisipasi politik seseorang, yaitu tingkat modernisasi suatu masyarakat, kondisi struktur sosial atau kekuasaan, tingkat mobilitas sosial, sistem politik atau aturan main, tingkat perkembangan demokrasi, dan sebagainya. ${ }^{11}$

\section{b. Peran Partai Politik}

Secara umum Partai Politik dapat mengambil peran menggerakan partisipasi politik rakyat bilamana secara konsisten menyelenggarakan fungsi-fungsi dasar sebagai partai politik yaitu: (a) menyalurkan aspirasi politik rakyat atau biasa disebut fungsi artikulasi dan agregasi kepentingan; (b) melakukan sosialisasi politik; (c) melakukan rekrutmen politik; (d) mengendalikan konflik. ${ }^{12}$ Fungsi-fungsi partai politik terjabar sebagai berikut:13

Pertama, sebagai sarana komunikasi politik, partai berperan sangat penting dalam upaya mengartikulasikan kepentingan (interests articulation) atau "political interests" yang terdapat atau kadang-kadang yang tersembunyi dalam masyarakat dan menyatupadukan dengan kepentingan politik yang lain (political agrigation). Berbagai kepentingan itu diserap sebaik-baiknya oleh partai politik menjadi ide-ide, visi dan kebijakan-kebijakan partai politik yang bersangkutan. Setelah itu, ide-ide dan kebijakan atau aspirasi kebijakan itu diadvokasikan sehingga dapat diharapkan mempengaruhi atau bahkan menjadi materi kebijakan kenegaraan yang resmi.

Kedua, Partai sebagai sarana sosialisasi politik. Partai politik juga memainkan peranan sebagai sarana sosialisasi politik (instrument of political socialization). Di dalam ilmu politik sosiali-sasi politik diartikan sebagai proses melalui mana seseorang memperoleh sikap dan orientasi terhadap fenomena politik, yang umumnya berlaku dalam masyarakat di mana ia berada. Biasanya proses sosialisasi berjalan secara berangsur-angsur dari masa kanak--kanak sampai dewasa. Di samping itu sosialisasi politik juga mencakup proses melalui mana masyarakat menyampaikan norma-norma dan nilai-nilai dari satu generasi ke generasi berikutnya. Ide, visi dan kebijakan strategis yang menjadi pilihan partai politik dimasyarakatkan kepada konstituen untuk mendapatkan 'feedback' berupa dukungan dari masyarakat luas. Terkait dengan sosialisasi politik ini, partai juga berperan sangat penting dalam rangka pendidikan politik. Partai lah yang menjadi struktur-antara atau 'intermediate structure' yang harus memainkan peran dalam membumikan cita-cita kenegaraan dalam kesadaran kolektif masyarakat warga negara.

Dalam hubungan ini partai politikberfungsi sebagai salah satu sa-rana sosialisasi politik. Dalam usaha menguasai pemerintahan me-lalui kemenangan dalam pemilihan umum, partai harus memperoleh dukungan seluas mungkin. Untuk itu partai berusaha menciptakan "image” bahwa ia memperjuangkan kepentingan umum. Di sam-ping menanamkan solidaritas dengan partai, partai politik jugs men-didik anggota-anggotanya 
menjadi manusia yang sadar akan tanggungjawabnya sebagai warga negara dan menempatkan kepen-tingan sendiri di bawah kepentingan nasional. Di negara-negara baru partai-partai politik juga berperan untuk memupuk indentitas nasio-nal dan integrasi nasional. Proses sosialisasi politik diselenggarakan melalui ceramah-cera-mah penerangan, kursus kader, penataran, dan sebagainya.

Ketiga, partai politik adalah sarana rekruitmen politik (political recruitment). Partai dibentuk memang dimaksudkan untuk menjadi kendaraan yang sah untuk menyeleksi kader-kader pemimpin negara pada jenjang-jenjang dan posisiposisi tertentu. Kader-kader itu ada yang dipilih secara langsung oleh rakyat, ada pula yang dipilih melalui cara yang tidak langsung, seperti oleh Dewan Perwakilan Rakyat, ataupun melalui caracara yang tidak langsung lainnya.

Tentu tidak semua jabatan dapat diisi melalui peranan partai politik sebagai sarana rekruitmen politik. Jabatan-jabatan profesional di bidang-bidang kepegawai-negerian, dan lain-lain yang tidak bersifat politik (poticial appointment), tidak boleh melibatkan peran partai politik. Partai hanya boleh terlibat dalam pengisian jabatanjabatan yang bersifat politik dan karena itu memerlukan pengangkatan pejabatnya harus melalui prosedur politik pula (political appointment).

Fungsi keempat, adalah pengatur dan pengelola konflik yang terjadi dalam masyarakat (conflict management). Seperti sudah disebut di atas, nilai-nilai (values) dan kepentingankepentingan (interests) yang tumbuh dalam kehidupan masyarakat sangat beraneka ragam, rumit, dan cenderung saling bersaing dan bertabrakan satu sama lain. Jika partai politiknya banyak, berbagai kepentingan yang beraneka ragam itu dapat disalurkan melalui polarisasi partaipartai politik yang menawarkan ideologi, program, dan altrernatif kebijakan yang berbeda-beda satu sama lain.
Dengan perkataan lain, sebagai pengatur atau pengelola konflik (conflict management) partai berperan sebagai sarana agregasi kepentingan (aggregation of interests) yang menyalurkan ragam kepentingan yang berbedabeda itu melalui saluran kelembagaan politik partai. Oleh karena itu, fungsi pengeloa konflik dapat dikaitkan dengan fungsi integrasi partai politik. Partai mengagregasikan dan mengintegrasikan beragam kepentingan itu dengan cara menyalurkannya dengan sebaik-baiknya untuk mempengaruhi kebijakan-kebijakan politik kenegaraan.

\section{HASIL DAN PEMBAHASAN}

Beberapa penelitian menunjukan bahwa partai politik cenderung terjebak dalam pusaran rutinitas kepartaian. Sangat sedikit kegiatan partai politik di luar masa kampanye pemilihan umum yang secara langsung bersentuhan dengan rakyat. Partai politik lebih banyak disibukan melakukan aktifitas konsolidasi internal kepengurusan dan pembekalan para caleg, itupun dalam jangka waktu relative pendek yaitu sekitar pemilu. ${ }^{14}$

Pada dasarnya, dalam upaya menggerakan partisipasi politik rakyat partai politik dapat berperan: Pertama, merubah psikologi politik masyarakat dari apatis, ditingkatkan menjadi pasif dan selanjutnya menjadi aktif serta melembaga. Salah satu cara yaitu partai memperbanyak informasi politik yang diterima rakyat melalui penguatan forum-forum rakyat (perempuan, pemuda, petani dll) dengan perangkat program pendidikan politik; Kedua, merubah kondisi social ekonomi rakyat. Meskipun pihak yang secara langsung mampu merubah kondisi social ekonomi masyarakat adalah domain eksekutif, akan tetapi melalui intensitas komunikasi politik yang berkualitas partai politik harus mampu meyakinkan rakyat bahwa partai politik adalah saluran yang terpercaya efektif memperjuangkan kepentingan rakyat; Ketiga, terus menerus memperbaiki design partai politik dari partai tradisional yang menggantung menjadi partai modern yang 
mengakar pada rakyat. Partai politik harus segera dapat membangun jaringan kepartaian sampai pada wilayah yang sangat kecil; Keempat, partai politik seyogyanya mendorong terus efektifitas politik pemerintah dengan menjadikan daerah otonom semakin kecil sehingga system keterwakilan betul-betul realities. Pada gilirannya, rakyat percaya bahwa kedaulatan ada ditangan mereka.

\section{KESIMPULAN}

Dalam upaya menggerakan partisipasi politik rakyat partai politik dapat berperan: Pertama, merubah psikologi politik masyarakat dari apatis, ditingkatkan menjadi pasif dan selanjutnya menjadi aktif serta melembaga. Kedua, merubah kondisi social ekonomi rakyat. Ketiga, terus menerus memperbaiki design partai politik dari partai tradisional yang menggantung menjadi partai modern yang mengakar pada rakyat. Keempat, partai politik seyogyanya mendorong terus efektifitas politik pemerintah dengan menjadikan daerah otonom semakin kecil sehingga system keterwakilan betul-betul realities.

\section{DAFTAR PUSTAKA}

Ikhlasul Amal,(eds) Teori-Teori Politik Mutakhir, Tiara Wacana Yogyakarta

M. Asfar,(eds), 2001, Implementasi Otonomi Daerah, CPPS, Surabaya

Miriam Budiardjo, 1981, Dasar-Dasar Ilmu Politik, Gramedia, Jakarta

Ramlan Surbakti, 1992, Memahami Ilmu Politik, Gramedia Widiasarana Indonesia, Jakarta

Robert A. Dahl,1971, Poliarchy: Participation and Opposition, NewHaven Conn: Yale University Press

\section{Footnote:}

1 Lihat Robert Dahl, 1971 h. 5-6

2 Misalnya Prilaku pejabat incumbent yang membatasi ruang gerak lawan politiknya dan atau memanfaatkan posisi politik untuk mendapatkan dukungan para birokrat.

$3 \quad$ Kompas, 11 Mei 2014

$4 \quad$ Ramlan Surbakti, 1992 h.141

5 Milbrath dan Goel dalam M. Asfar, 2001 h. 239

6 Gamson, dalam M. Asfar, 2001 h. 240

$7 \quad$ Verba and Nie, dalam ibid

8 Wolfinger and Rosenstone dalam M. Asfar, 2001 h. 247

$9 \quad$ Sherman and Kolker, dalam M. Asfar, 2001 h. 247

10 Ibid., h. 248

11 Milbath and Goel, dalam Ramlan Surbakti, 1992 h. 147

12 Lihat Miriam Budiardjo, 1981, h. 163-164 ; Ramlan Surbakti, 1992 h. 140-148; Roy MacRidis dalam Ikhlasul Amal, 1996 h. 1734

13 Lihat, Miriam Budiardjo,1981 ibid, Lihat juga Jimly Asshiddiqie, Dinamika Partai Politik dan Demokrasi, Makalah Tanpa Tahun.

14 Lihat penelitian, Baharuddin, Optimaslisasi Peran Partai Politik Dalam Meningkatkan Partisipasi Politik Masyarakat Pada Pemilu Legislatif Berdasarkan Undang Undang Nomor 2 Tahun 2008 Tentang Partai Politik 